\title{
Marx's defence of Jewish emancipation and critique of the Jewish question
}

The Jew ... must cease to be a Jew if he will not allow himself to be hindered by his law from fulfilling his duties to the State and his fellow-citizens. (Bruno Bauer, Die Judenfrage $)^{1}$

The Jews (like the Christians) are fully politically emancipated in various states. Both Jews and Christians are far from being humanly emancipated. Hence there must be a difference between political and human emancipation. (Marx and Engels, The Holy Family) ${ }^{2}$

Capitalism has not only doomed the social function of the Jews; it has also doomed the Jews themselves. (Abram Leon, 'Toward a Solution to the Jewish Question') ${ }^{3}$

Within the eighteenth-century Enlightenment, the perspectives of Jewish emancipation and the Jewish question were synthesised to the extent that emancipation was justified in terms of solving the Jewish question. Within the French Revolution, the inclusive face of universalism that was articulated in the Declaration of the Rights of Man and Citizen was synthesised with the terror directed at those labelled 'enemies of humanity'. In both the Enlightenment and the revolutionary tradition, however, there were alternative ways of thinking about Jewish emancipation that sought to break radically from the prejudicial assumptions of the Jewish question. In the nineteenth century, the synthesis of Jewish emancipation and the Jewish question was to be torn apart. On the one hand, the Jewish question was set in opposition to Jewish emancipation; on the other hand, Jewish emancipation was justified independently of the Jewish question. ${ }^{4}$ The tensions contained in the eighteenth-century synthesis could no longer be held in check.

In the 1820s, the emergent opposition between Jewish emancipation and the Jewish question may be illustrated through the debate between the older and allegedly more conservative Hegel and the radical German populist and student radical, Jacob Fries. In a pamphlet titled On the Danger Posed to the Welfare and 
Character of the German People by the Jews, Fries maintained that the harm caused by Jews was such that they should be prohibited from establishing their own educational institutions, marrying Gentiles, employing Christians as servants or entering Germany, that they should be forced to wear a distinctive mark on their clothing and that they should be encouraged to emigrate. ${ }^{5}$ Fries' depiction of the Jews as the enemy of the people was coupled with the revolutionary conviction that all political life must derive exclusively from the people, a category from which the Jews were excluded.

Hegel argued that the superficial attraction of Fries' radical populism was the mix of 'heart, friendship and enthusiasm' on which it was based, but he maintained that the hatred and contempt Fries showed for rights, law and the state was 'the chief shibboleth whereby false friends of "the people" give themselves away'. Hegel demonstrated that it is a matter of 'infinite importance' that 'a human being counts as such because he is a human being, not because he is a Jew, Catholic, Protestant, German, Italian, etc.' and that when we speak of Jews as human beings 'this is not just a neutral and abstract quality ... for its consequence is that the granting of civil rights gives those who receive them a selfawareness as recognised legal persons in civil society'. Hegel repudiated those who sought to deny civil and political rights to Jews on the pretext that the Jews were a foreign nation and not an integral part of the people: 'If they had not been granted civil rights, the Jews would have remained in that isolation with which they have been reproached, and this would rightly have brought blame and reproach upon the state which excluded them'. ${ }^{6}$

Hegel's robust repudiation of Fries' false radicalism was, as it were, the first salvo of a struggle resumed twenty years later, in the 1840s, in the debate between the radical 'Young Hegelian' Bruno Bauer and Karl Marx over the Jewish question in Germany. Paradoxically, it was in the spirit of the 'conservative' Hegel that Marx distanced himself from the 'radical' Young Hegelian. It is to this debate we now turn.

\section{Re-reading Marx}

Two views prevail concerning Marx's own relation to the Jewish question. The disparaging view is that Marx, notwithstanding his Jewish origins, was an antisemite avant la lettre and that he made use of antisemitic stereotypes and tropes in his critique of capitalism. This view is pronounced among scholars of modern antisemitism and draws sustenance above all from the second of Marx's two 1843 essays 'On the Jewish Question', where he appears to link Judaism with the cult of money, and to associate human emancipation with emancipation from Judaism. His writings have been situated in a tradition Julius Carlebach calls 'the radical critique of Judaism' - a tradition that prefigured the 'left antisemitism' to come. 
The apologetic view adopted above all by Marxist commentators has tended to ignore the seemingly antisemitic aspects of Marx's writings, or to trivialise them as passing prejudices that did not enter into his scientific work, or to normalise them as a characteristic sign of Marx's own times, or to translate them into a more acceptable language of anti-capitalism (e.g., by translating Judentum into 'commerce'), or, finally, to defend them on the grounds that they reflected accurately the social role of Jews at the time. We are critical of both these ways of reading Marx.

The problem with the disparaging view is that, beyond the second essay, 'On the Jewish Question', there is not much compelling evidence of anti-Judaic thinking in Marx's writings. Marx is accused of deploying racist and antisemitic epithets in private correspondence with Engels. An often-cited case is his depiction of Ferdinand Lassalle as 'Jude Itzig', a term used by Jews to mock the grandiose pretensions of other Jews. Marx was referring in this letter to Lassalle's predilection for the pseudo-science of physiognomy. In another letter to Engels, Marx made fun of Lassalle's own 'smooth, self-important, vainglorious, deceitful charlatan's physiognomy' and in yet another he expostulated that Lassalle 'proved by his cranial formation and hair' that he 'descends from the Negroes who had joined Moses' exodus from Egypt'. ${ }^{8}$ In reading this private correspondence, we may accuse Marx of bad taste or chuckle at his acerbic wit but there is no evidence that he had anything other than disdain for Lassalle's belief in physiognomy and for the authoritarian and illiberal conception of socialism of which this was part. Marx was clearly making fun of his socialist opponent.

There is occasional use of anti-Jewish epithets in Marx's political articles. In an article entitled 'The Russian Loan', probably written by Engels but published under Marx's name in the New York Daily Tribune (4 January 1856), 'Marx' writes: 'We find every tyrant backed by a Jew, as is every Pope by a Jesuit. In truth, the cravings of oppressors would be hopeless, and the practicality of war out of the question, if there were not an army of Jesuits to smother thought and a handful of Jews to ransack pockets ... The real work is done by the Jews, and can only be done by them ... as they monopolise the machinery of the loanmongering mysteries'. Was Marx's attack on Jewish finance alongside that on Jesuit ideology antisemitic? Two years earlier (15 April 1854) he had expressed outrage over the poverty of Jews in Ottoman-ruled Jerusalem, commenting: 'Nothing equals the misery and the sufferings of the Jews at Jerusalem, inhabiting the most filthy quarter of the town ... the constant objects of Mussulman oppression and intolerance'. Whether or not any of these articles should be considered antisemitic, or Islamophobic or anti-Catholic, we may leave to our readers. We might well wish to place them in a tradition of radical criticism of the 'economic Jew' - not unlike, say, Irene Nemirovsky's critique of a rich Jewish merchant modelled on her father in her 1929 novel David Golder.

The more telling objection to this reading of Marx, however, lies in the unequivocal support he and Engels gave to Jewish emancipation in Germany and in 
the very strong opposition they expressed toward left thinkers who either opposed Jewish emancipation or made it conditional on Jews in some way 'improving' themselves. Many of the left intellectuals Marx and Engels most strongly criticised had antisemitic or proto-antisemitic leanings: not just the young Hegelian Bruno Bauer, to whom Marx's essays 'On the Jewish Question' were a response, but also the anarchist Pierre-Joseph Proudhon, the co-operative socialist Charles Fourier, the radical philosopher Eugen Dühring, the insurrectionist socialist Louis-Auguste Blanqui, and the revolutionary anarchist and pan-Slavist, Mikhail Bakunin. ${ }^{10}$ Marx's and Engels' criticisms of these and like-minded authors were directed in part at their anti-Jewish prejudices and more especially at the political and intellectual limitations of which these prejudices were symptomatic. These critiques indicate how actively and purposefully Marx and Engels confronted anti-Judaic and antisemitic currents running through the 'left'.

When we turn to the apologetic view of Marx's relation to antisemitism, we find that it is no better grounded. The proposition that Marx's thinking was universalistic and, as such, incompatible with antisemitism can only be sustained if one ignores the Enlightenment legacy. The proposition that Marx's stereotyping of Jews was a valid attempt to explore the rational kernel of the Jewish question presupposes the truth-content of anti-Judaic prejudices: for example, that the Jews demand their own rights but not those of others, that the Jews stand for their own emancipation but not for the general cause of emancipation, that the Jews exempt Judaism from normal procedures of open criticism, etc. Some commentators endorse what they take to be Marx's own view, that Jewish emancipation should have been postponed until Jews superseded their Judaism or that the sooner Judaism disappeared, the better it would have been for society and for the Jews themselves. Some commentators have failed to distinguish Marx's views from Bruno Bauer's anti-Judaic contentions, for example, that 'the same people ... who watch with pleasure when Christianity is subjected to criticism are capable of condemning anyone who also wants to subject Jewry/Judaism to criticism', or Bauer's equally anti-Judaic contention that 'the defenders of Jewish emancipation have hence appropriated the odd position of fighting against privileges and at the same time granting Jewry/Judaism the privilege of immutability, invulnerability and unaccountability'. ${ }^{11}$ Some have more disgracefully defended Marx's second essay 'On the Jewish Question' on the grounds that it revealed the real links that existed between Judaism and the 'spirit of the usurer and the trickster. ${ }^{12}$ The legacy of this misreading of Marx has been to encourage Marxists to work on the assumption that there was a 'Jewish question' to solve and to encourage scholars of antisemitism to treat Marx and Marxism as part of the problem. ${ }^{13}$

We argue that both interpretations, the disparaging antisemitic interpretation and the apologetic Marxist interpretation, conceal what is innovative and original in Marx's contribution to the critique of the Jewish question. In opposite ways 
they both serve to situate Marx within the bounds of the Jewish question. We need to find a way of re-reading Marx and his actual texts without the weight of this ideological baggage. At stake here for us is not just how to evaluate Marx himself but also how to recognise and reconstruct a tradition of critical theory that is able to face up to the phenomena of antisemitism.

\section{The grammar of Marx's critique of the Jewish question}

In a contribution to public debate on the Jewish question in Germany, Bruno Bauer, a Young Hegelian and radical theologian, put his weight behind the cause of humanity to which, he argued, Judaism was fundamentally hostile. According to Bauer, while human history is a process of development, the Jews have shown themselves incapable of evolving with it: they cannot grow spiritually as human beings; they have no care for universal human concerns; by presenting themselves as the 'chosen people' they purport to stand apart from and above all other human beings; they claim discrimination at the hands of European society but actually exercise prodigious financial power over it. If Jews are to be considered for emancipation, Bauer concluded, they would have to demonstrate commitment to the general cause of humanity and they could do so only by abolishing Judaism. As Bauer put it: 'As long as he is a Jew, the restricted nature that makes him a Jew will inevitably gain the ascendancy over the human nature which should join him as a man to other men'. ${ }^{14}$ Bauer may be read as radicalising the restrictions on Jewish emancipation imposed by the Jewish question.

In Marx's first essay 'On the Jewish Question' he begins with his own paraphrase of Bauer's argument:

You Jews are egoists if you demand a special emancipation for yourselves as Jews. You should work as Germans for the political emancipation of Germany and as men for human emancipation and you should look upon the particular form of oppression and shame which you experience not as an exception to the rule but rather as a confirmation of it ... The Jew by his very nature cannot be emancipated ... The Jew himself can behave only like a Jew towards the state, i.e. treat it as something foreign, for he opposes his chimerical nationality to actual nationality, his illusory law to actual law, he considers himself entitled to separate himself from humanity, he refuses in principle to take any part in the movement of history, he looks forward to a future which has nothing in common with the future of humankind as a whole, and he sees himself as a member of the Jewish people and the Jewish people as the chosen people. ${ }^{15}$

Marx then unravels step by step the poverty of Bauer's theory. Bauer anachronistically based his attack on Judaism on the role once played by Jewish finance in the development of capitalism but no longer operative. He pathologised this role as wholly negative and naturalised it as an essential property of Judaism. 
Other critics of Bauer had revealed his ignorance of contemporary Jewish life. According to Moses Hess, for instance, Bauer's association of Judentum with egoism revealed that he knew little about Jewish society: 'Nothing is more foreign to the spirit of Judaism than the egoistic salvation of the isolated individual ... No nation refutes egoism more strongly than the Jewish'. Heinrich Heine declared wittily, 'Some think they know the Jews because they have seen their beards.$^{16}$ Marx's approach was different: it was not to challenge Bauer on the empirical grounds that Jews were not as bad as he portrayed them to be, but rather to turn the argument on its head and challenge the assumptions that lay behind it. Jews were manifestly a more complex, differentiated, plural and class-divided category of people than Bauer acknowledged, but the issue was how to release the question of Jewish emancipation from the grip of the so-called Jewish question. ${ }^{17}$

Marx supported Jewish emancipation unequivocally and without conditions: 'We do not tell the Jews that they cannot be emancipated politically without radically emancipating themselves from Judaism, which is what Bauer tells them. ${ }^{18}$ While Bauer asked why Germans should be interested in the liberation of the Jew if the Jews were not interested in the liberation of the Germans, Marx inverted this question: 'Does the standpoint of political emancipation have the right to demand from the Jews the abolition of Judaism and from man the abolition of religion?"19 To Bauer's assertion that 'the Christian state ... cannot allow adherents of another particular religion ... complete equality with its own social estates', Marx observed that in France (partially) and North America (more fully) Jews, like Christians, are politically emancipated and concluded that states which did not yet politically emancipate Jews must be rated negatively by comparison with the 'perfected political state' and shown to fall short. ${ }^{20}$ Marx understood that the Jewish question was in actuality a German question: it was not about the Jews but about Germany's capacity to enter the modern world. Behind Bauer's opposition to Jewish emancipation was an inability to understand how modern society works. Freedom of religion does not mean freedom from religion but the right to be religious or not in any way one wishes. In the United States, Marx observed, there was no state religion and yet it was 'the land of religiosity par excellence'. ${ }^{21}$ Religious freedom does not signify abolition of religious commitments and distinctions, but only of their political significance for suffrage, property rights and occupational access. Freedom of religion signifies that religion becomes a private right and the state becomes a secular state.

Marx did not reject the distinction Bauer adopted between political and human emancipation but what he did with it was contrary to what Bauer did with it. Bauer appealed to human emancipation against political emancipation, maintaining that to overcome the egoism, false equality and abstraction of rights was the condition of creating the 'real harmonious species-life of man'. ${ }^{22}$ Marx treated the Declaration of the Rights of Man and Citizen as a 'great step 
forward', ${ }^{23}$ which marked the difference between 'the modern representative state and the old state of privileges' and which for the first time turned the 'affairs of state into the affairs of the people. ${ }^{24}$ Marx recognised the limits of political emancipation: "The fact that you can be politically emancipated without ... renouncing Judaism shows that political emancipation by itself is not human emancipation'.$^{25}$ This recognition was not designed, however, to devalue political emancipation or treat it as a mere stepping-stone to be discarded once human emancipation was achieved, but to redeem it as a necessary though insufficient component of human emancipation. Marx perceived an intrinsic relation between political and human emancipation: political emancipation is not human emancipation but there can be no human emancipation without political emancipation. Marx famously observed that 'not one of the so-called rights of man goes beyond egoistic man, man as a member of civil society, namely an individual withdrawn into himself, his private interest and his private desires, and separated from the community. ${ }^{26}$ This comment appears to indicate congruity between Marx and Bauer to the extent that both considered right to be an expression of bourgeois egoism, but the logic of Marx's argument is quite different from that of Bauer: it is that since none of the rights of man goes beyond the egoistic individual separated from the community, it makes no sense to exclude the Jews on the grounds of their alleged egoism and separation from the community.

The language of the second essay 'On the Jewish Question' is nevertheless troubling. Let us quote from the Penguin translation to give a flavour of just how troubling:

What is the secular basis of Judaism? Practical need, self-interest. What is the secular cult of the Jew? Haggling. What is his secular God? Money. Well then! Emancipation from haggling and from money, i.e. from practical, real Judaism, would be the same as the self-emancipation of our age ... We therefore recognise in Judaism the presence of ... a contemporary anti-social element whose historical evolution - eagerly nurtured by the Jews in its harmful aspects - has arrived at its present peak, a peak at which it will inevitably disintegrate. The emancipation of the Jews is in the last analysis the emancipation of humankind from Judaism ... Money is the jealous God of Israel before whom no other God may stand ... Exchange is the true God of the Jew. His God is nothing more than illusory exchange ... What is present in an abstract form in the Jewish religion - contempt for theory, for art, for history, for man as an end in himself - is the actual and conscious standpoint, the virtue, of the man of money ... The chimerical nationality of the Jew is the nationality of the merchant, of the man of money in general ... The ungrounded and unfounded law of the Jew is only the religious caricature of ... the purely formal rites with which the world of self-interest surrounds itself. Here too the supreme relation of man is the legal relation, the relation of laws which apply to him not because they are the laws of his own will and nature but because they dominate him and because breaches of them would be 
avenged ... As soon as society succeeds in abolishing the empirical essence of Judaism - the market and the conditions which give rise to it - the Jew will have become impossible ... The social emancipation of the Jew is the emancipation of society from Judaism. ${ }^{27}$

This text summarises rather succinctly the key prejudices contained in the Jewish question and endorsed by Bauer. Should we read these prejudices as representative in any way of Marx's own views? If so, how are we to treat the relation between Marx's defence of Jewish emancipation and critique of the Jewish question in the first essay, written only weeks earlier, and this mouthful of anti-Judaic stereotypes in the second? One possible answer is that Marx was more like Bauer than we suggest, the difference between them boiling down to the difference between one who demands that Jews give up Judaism as a condition of political emancipation and one who advances political emancipation for Jews in the hope and expectation that they will then give up their Judaism. This interpretation, however, cannot explain the second essay's discontinuity with his first essay or indeed with Marx and Engels' biting restatement of their critique of Bauer in The Holy Family written shortly afterward. In this text, Marx and Engels were even more scathing about Bauer's attempt to justify the exclusion of Jews from political society in terms of their self-exclusion from civil society, to debase not just Jewish emancipation but political emancipation as such as the 'illusion of the masses', and label Marx and Engels themselves derogatorily as "representatives of the mass': "How low "the mass" is in comparison with holy criticism', Marx and Engels jibed in response. ${ }^{28}$

If we are to retain the unity of Marx's three responses to Bauer - that is, the first and second essays on the Jewish question and then parts of The Holy Family - we need to trace the common logic running through them. We can do so along the following lines.

Since the rights of man and citizen include freedom of religion, what grounds can there be for excluding Jews because of their religion?

Since the rights of man include rights of egoism, what grounds can there be for denying civil rights to Jews because of their alleged egoism?

Since the rights of citizen abstract 'political man' from their social role, what grounds can there be for excluding Jews because of their allegedly harmful social role?

Since money in modern society is the supreme world power, what grounds can there be for denouncing Jews for allegedly turning money into their God?

While Bauer represents the Jew as 'moneyman', Marx responds that in the modern world 'money has become a world power'. While Bauer imagines that 
money is 'the practical spirit of the Jews', Marx responds that money has also become 'the practical spirit of the Christian peoples'. While Bauer says that money is the 'jealous God of Israel', Marx responds that the God of the Jews has become the God of the world. After Marx, no longer can the defence of Jewish emancipation be grounded in assumptions about the goodness of 'Christian civil society' or the badness of 'Jewish tribalism'.

This interpretation of Marx has the advantage of upholding the unity of his texts. It also gives body to a universalism that has no truck with the Jewish question. The real question for Marx was whether a backward state like Germany could catch up with modern states like the US and France, which had already granted equal rights to Jews. His defence of Jewish emancipation drew sustenance from the radical wing of Enlightenment in its radical attack on the whole mindset of the Jewish question. It was not just a critique of Bauer but of the Jewish question itself and of the place it occupied in Enlightenment and the modern revolutionary tradition. Bauer went on to paint Jews as 'white Negroes' and to propose shipping Jews to 'the land of Canaan'; Marx and Engels went on to develop their critique of the economic forms of capitalist society. There lies a fundamental and critical difference.

\section{Real humanism and the Jewish question}

We do not wish to suggest that there was nothing in any of Marx and Engels' conception of human emancipation that was not open to being read through the lens of the Jewish question, only that this reading misconstrues the 'real humanism' they sought to nurture. As the philosopher Karl Löwith puts it in his monograph Max Weber and Karl Marx, Marx sometimes appeared to identify human emancipation with 'emancipation from every kind of particularity in human life as a whole; from the specialisation of occupations just as much as from religion and privatisation'. ${ }^{29}$ In History and Class Consciousness the Marxist philosopher, Georg Lukács, maintained that the consciousness of the worker under capitalism becomes no more than the 'self-consciousness of the commodity' and that it is only when every particular human element has been taken away that workers can begin to conceive of human emancipation 'uncontaminated by any trace of reification'. ${ }^{30}$ A conception of human emancipation as emancipation from every kind of particularity - property, family, gender, religion, nationality, occupation, etc. - appears to leave no space for the particularity of Judaism. If 'the Jews' are viewed through the lens of the Jewish question as the very personification of the particular, it becomes but a short step to conclude that for Marx emancipation from Judaism was a crucial step in the emancipation of humanity from all particulars and all traces of reification. It is hard to imagine in these interpretations of human emancipation what place there could be for Jews or Judaism in the communist future. This reading of 
human emancipation might appear to be anticipated by the homage Marx and Engels paid in The Communist Manifesto to the dissolving effects of bourgeois society:

The bourgeoisie cannot exist without constantly revolutionising the instruments of production and thereby the relations of production, and with them the whole relations of society ... Constant revolutionising of production, everlasting uncertainty and agitation distinguish the bourgeois epoch from all earlier ones. All fixed, fast frozen relations, with their train of ancient and venerable prejudices and opinions, are swept away ... All that is solid melts into air ... All that is holy is profaned ... The bourgeoisie ... has left no other bond between man and man than naked self-interest ... The bourgeoisie has resolved personal worth into exchange value ... The bourgeoisie has drowned ... religious fervour ... in the icy waters of egoistical calculation ... The bourgeoisie has stripped of its halo every occupation hitherto honoured ... The bourgeoisie has torn away from the family its sentimental veil. ${ }^{31}$

In imagery drawn from Shakespeare's Tempest, capitalist society is portrayed as leaving no other nexus between human beings than that of naked self-interest. All particulars - property, culture, family, marriage, childhood, education, country, religion, morality, occupation, personal worth - are reduced to a money relation. There is nothing that bourgeois society cannot destroy and surpass even itself.

In facing up to the revolutionary iconoclasm of the bourgeoisie, Marx and Engels express no nostalgia for the annihilated past, but endeavour to turn the destructive nihilism of the bourgeois into the affirmative communism of the proletarian. Since workers are left like Nietzsche's 'last man' without name, individuality or place, nothing can be taken from them because all has already been taken: workers become slaves to capital, appendages to the machine, commodities to be bought and sold on the market place, for whom all values appear as bourgeois prejudices. If communism is their movement and has no interests apart from those of the proletariat as a whole, then the aim must be to abolish particularity for all since capitalism has already abolished it for the masses. The workers have a world to win, not by restoring old values, but by harnessing the destructive energy of bourgeois culture for the creation of a more human world.

After the defeats of the 1848 revolutions, the crucial development in Marx's political thought lay in his recognition that the modern worker is not a commodity but the owner of commodities and therefore a person, a human being in the substantial sense of the term. Workers have more to lose than their chains, which is just as well if they have a world to win. While their labour-power has been turned into a commodity, they themselves have become subjects, owners of their own labour-power, possessors of at least this form of property. It is this 
quality of personality belonging to workers that Marx sees as the beginning of their long and arduous journey in the development of human self-emancipation.

What arose against and after Marx was a tendency within official Marxism to turn the denial of the right of particularity into a fixed doctrine: to treat human beings as units in a chain of determined circumstances, to evaporate the active side of human life and to reify the universal. One of the manifestations of this 'heresy against man', as the Marxist historian Edward Thompson aptly put it, was to make possible the reconfiguration of the Jewish question. This was not the path taken by Marx and Engels, who came to recognise that workers in capitalist society are not mere commodities but owners of commodities, at least their own labour-power, and that they are therefore rights-bearing subjects with more to lose than their chains. The defence of subjective rights developed by Marx after 1848 was continuous with that of the young Marx in his critique of the Jewish question. Neither Marx nor Engels were afraid of combating forms of 'socialism' that were capable, as they put it in The Communist Manifesto, of no more than 'hurling the traditional anathemas' against bourgeois liberties and representing the Jews as 'a secret world power which makes and unmakes governments. ${ }^{32}$

For Bauer and those 'Marxists' who followed in his footsteps, human emancipation was premised on imagining 'a world without Jews', but the vista of human emancipation Marx and Engels put forward was shaped by an altogether less repressive vision. In the final paragraph of Marx's first essay he introduced the following formulation:

Only when real individual man resumes the abstract citizen into himself and as an individual man has become a species-being in his empirical life, his individual work and his individual relationships, only when man has recognised and organized his forces propres as social forces so that social force is no long separated from him in the form of political force, only then will human emancipation be completed. ${ }^{33}$

The meaning of this passage is not self-evident but we find here a conception of human emancipation that is not based on excluding 'the Jews' for failing some test of human universality but on developing individuality to its maximum extent and overcoming the dominance of abstraction over human life. The exemplar of the dominance of abstractions over human life is that of 'the Jews' over real individual Jews. 'Real humanism' is predicated on recognising the humanity of Jews in their individuality, that is, in their empirical life, work and relationships. In defending Jewish emancipation against the restoration of the Jewish question, Marx re-affirmed the subjective right of Jews to be citizens, to be Jews, and to deal creatively, singularly, in their own way, with their Jewish origins. Real humanism is a revolt against the tyranny of provenance. 
The humanist Marx we are endeavouring to uncover is doubtless not the only Marx we could find, and we are aware that we have to shake off thick clouds of interpretive obfuscation to see its outlines. Our conviction, though, is that an interpretation of this kind does justice to the unity and integrity of Marx's texts, as well as to an authorship that would have no truck with the repressive demands of the Jewish question even in its left wing manifestations. Marx's early essays on the Jewish question actually ushered in a lifelong critique of antisemitism. They showed that the point of view of the Jewish question is not an inevitability; that it can be overcome. Marx's essays remain, for all their ambiguities, a key resource for recovering a tradition of critical thought that repudiates "left antisemitism'. We should be sceptical both of the claim that Marx personally or politically exhibited anti-Jewish prejudices and of the claim that this was in some fundamental way characteristic of the left. What seems more important to us is that Marx fought against the mainstreams of contemporary radicalism and socialism, which were drawn to the assumptions of the Jewish question and in some cases helped to reconfigure it. This is not say that Marx should bear no responsibility for becoming dramatically and fatefully misappropriated, since the ambiguities of his second essay on the Jewish question, and of his writings on human emancipation, allowed the Jewish question to be smuggled back in. The Marx we find, however, is the child of Enlightenment who struggled to emancipate the Enlightenment from its own anti-Judaic prejudices. His contribution was to dissociate the right to rights of all human beings from substantive notions of particular communal worth, to justify the right of Jews to emancipation without resort to any form of the Jewish question (including Jewish claims to the universality of Judaism), to demonstrate the ties that bound the Jewish question to a wider devaluation of human rights, and to map the poisoned terrain on which modern antisemitism was rising. He was not alone in this endeavour but his voice became ever harder to hear over time as antisemitism set in and the Jewish question also infused its opposition. It is to Marxist appropriations and misappropriations of Marx's critique of the Jewish question that we now turn.

\section{Notes}

1 Bruno Bauer, Die Judenfrage (The Jewish Question).

2 Karl Marx and Friedrich Engels, The Holy Family or Critique of Critical Criticism: Against Bruno Bauer and Company (Moscow: Progress, 1980).

3 Abram Leon, 'Toward a Solution to the Jewish Question', The Jewish Question: A Marxist Interpretation (New York: Pathfinder Press, 1979 [original French edition, 1946])

4 For a more general discussion of how the Enlightenment synthesis broke into extremes, see Karl Löwith, From Hegel to Nietzsche (New York: Anchor, 1967), $240 \mathrm{ff}$. 
5 See Shlomo Avineri, Hegel's Theory of the Modern State (Cambridge: Cambridge University Press, 1972), 119-121. He characterises the political current represented by Fries as 'proto-fascist'.

6 Hegel, Elements of the Philosophy of Right, 'Preface', 15-16. Emphasis in original.

7 Among compelling examples of the disparaging view of Marx's proto-antisemitism are: Julius Carlebach, Karl Marx and the Radical Critique of Judaism (London: Routledge and Kegan Paul, 1978); Francis Kaplan, Marx Antisémite? (Paris: Berg International, 1990); Edmund Silberner, 'Was Marx an Antisemite?', Historica Judaica, 2 (1), 1949: 3-52; Rose, Revolutionary Antisemitism in Germany, 296-305; Paul Johnson, A History of the Jews (London: Phoenix, 1994), 350-352; Shlomo Avineri, 'Marx and Jewish Emancipation', Journal of the History of Ideas, 25 (3), 1964: 445-450; Alexander, The Civil Sphere, 485-488; and Nirenberg, Anti-Judaism, 430-439.

8 The quotations are drawn from letters from Marx to Engels on 6 June 1853, 30 July 1862, and 29 May 1863. See Karl Marx and Friedrich Engels, Letters, www.marxists.org/ archive/marx/letters/date/ (accessed 28 November 2015).

9 Julius Carlebach records that at the time of Marx's 1843 writings small traders and hawkers constituted 66\% of the Jewish working population in Prussia and the great majority of the working population in Eastern Europe. Marx acknowledged the historic role of some Jews in commerce and moneylending in pre-modern societies but saw it replaced by more systematic processes of national capital accumulation. See Carlebach, Karl Marx, 56.

10 For firm evidence of their antisemitism see Pierre-André Taguieff, La Judéophobie des Modernes: des Lumières au Jihad Mondial (Paris: O. Jacob, 2008).

11 The misappropriation of Marx by Marxists on the Jewish question is discussed in depth in Lars Fischer's The Socialist Response to Antisemitism in Imperial Germany (Cambridge, New York: Cambridge University Press, 2007), 37-102. The passages Fischer quotes here (pp. 53-54) are from Franz Mehring, one of the leading Marxist intellectuals of the Second International. Elsewhere Mehring writes: 'Marx regards Judaism as a general, contemporary, anti-social element driven to its present height by historical development and the zealous co-operation of the Jews themselves, a height at which it must necessarily dissolve itself'. Franz Mehring, Karl Marx, trans. Edward Fitzgerald (Ann Arbor: Ann Arbor Press, 1962 [1918]), 72-73.

12 Cited from, of all people, Rosa Luxemburg by Traverso, The Marxists and the Jewish Question, 16. For discussion of Marxist responses to Marx see Fischer, The Socialist Response to Antisemitism in Imperial Germany, 37-102.

13 Jeffrey Alexander finds 'striking parallels' between representations of Jews in the eighteenth-century Enlightenment and in the nineteenth-century revolutionary tradition. He argues, mistakenly in our view, that Marx's antisemitic stereotypes help explain why Marxist movements subsequently displayed such 'powerful antisemitic overtones'. Alexander, The Civil Sphere, 486-488.

14 Bruno Bauer, The Jewish Problem, trans. Helen Lederer (Cincinnati: Hebrew Union College, 1958).

15 Karl Marx, 'On the Jewish Question' in Lucio Colletti (ed.), Karl Marx's Early Writings (Harmondsworth: Penguin, 1975), 210-241 at 212. 
16 Cited in Draper, Karl Marx's Theory of Revolution, Volume I State and Bureaucracy, 593.

17 Jean-Paul Sartre was to observe how resistant the antisemitic outlook can be to empirical criticism. In Antisemite and Jew (1946) he described antisemitism as a 'passion' neither caused nor refutable by experience: 'The essential thing here is not a "historical fact" but the idea that the agents of history formed for themselves of the Jew'. Sartre observed that there is a sense in which the antisemite can never lose the argument. If we point out that most Jews are not powerful financiers or that most powerful financiers are not Jews, the antisemitic imagination remains no less fixed on the powerful Jewish financier. Marx's refusal to challenge Bauer on empirical grounds may be viewed as being based on similar premises. See Jean-Paul Sartre, Antisemite and Jew (New York: Schocken Books, 1965 [1946]), 15.

18 Marx, 'On the Jewish Question', 226. Emphasis in original.

19 Marx, 'On the Jewish Question', 216.

20 Marx, 'On the Jewish Question', 220.

21 Marx, 'On the Jewish Question', 217.

22 Marx, 'On the Jewish Question', 222.

23 Marx, 'On the Jewish Question', 221.

24 Marx, 'On the Jewish Question', 232. Jewish emancipation was later to be followed by antisemitic reactions revoking Jewish emancipation, expelling Jews from a particular territory or eliminating them from the world. This reaction indicates why it remains essential to distinguish between political emancipation and human emancipation.

25 Marx, 'On the Jewish Question', 226.

26 Marx, 'On the Jewish Question', 230.

27 Marx, 'On the Jewish Question', 236-237.

28 Marx and Engels, The Holy Family or Critique of Critical Criticism, 98-154.

29 Karl Löwith, Max Weber and Karl Marx (London: Routledge, 1993), 106.

30 Georg Lukács, History and Class Consciousness: Studies in Marxist Dialectics (Cambridge, MA.: MIT Press, 1971), 178; 184.

31 Karl Marx and Friedrich Engels, 'The Communist Manifesto' in Karl Marx and Friedrich Engels, Selected Works in One Volume (London: Lawrence and Wishart, 1970), 31-63, at 38 .

32 Marx and Engels, Communist Manifesto, 57.

33 Marx, 'On the Jewish Question', 234. Emphasis in original. 